\title{
Aplikasi Herbisida Ramah Lingkungan di Desa Kiusili Kecamatan Bikomi Selatan Kabupaten Timor Tengah Utara
}

\author{
Gebhardus Djugian Gelyaman $^{1)}$, Yolanda Getrudis Naisumu ${ }^{2}$, Aloysius Rusae ${ }^{3)}$ \\ Kimia, Pertanian, Universitas Timor, Indonesia ${ }^{1)}$,Biologi,Pertanian,Universitas Timor ${ }^{2)}$ Agrotek, \\ Pertanian, Universitas Timor, Indonesia ${ }^{3)}$ \\ Pos-el: hagigelyaman@gmail.com ${ }^{11}$;yolandanaisumu@gmail.com ${ }^{21}$;alorusae@yahoo.com ${ }^{3)}$
}

\begin{tabular}{|l|l|l|}
\hline Dikirim: 05,11, 2019 & Direvisi: 6,02, 2020 & Diterbitkan: 28, 02, 2020 \\
\hline
\end{tabular}

\begin{abstract}
Abstrak
Telah dilakukan pengabdian pada masyarakat di kelompok tani Nek'amnaut Desa Kiusili kabupaten Timor Tengah Utara. Pengabdian berupa penggunaan herbisida ramah lingkungan yang terbuat dari garam, cuka, air dan sabun cair. Metode pengabdian berupa sosialisasi dan demo pembuatan serta penyermprotan larutan tersebut pada gulma. Pengisian quisioner pra pengabdian dan pasca pengabdian dilakukan guna mengetahui pengetahuan terkait herbisida pada umumnya dan kemampuan masyarakat membuat herbisida ramah lingkungan.

Hasil menunjukkan bahwa larutan herbisida ramah lingkungan berhasil membunuh gulma. Pengetahuan masyarakat berubah dari kategori tidak tahu menjadi berpengetahuan baik,ditandai peningkatan skor pengetahuan (SP)dari 24 menjadi 76. Presentase jumlah warga yang mengalamiperubahan kategori iniadalah 0 menjadi $83 \%$.Kemampuan masyarakat berubah dari tidak mampu membuat menjadi sangat mampu membuat herbisida tersebut, ditandai skor kemampuan (SK) meningkat dari 0 menjadi 83. Presentase jumlah masyarakat yang mengalami perubahan kategori kemampuan adalah dari 0 menjadi 89\%.Penurunan intensitas penggunaan herbisida sintetik terjadi dalam tiga tahun terakhir.Sebanyak 5 liter larutan herbisida ramah lingkungan mampu membunuh gulma seluas $48 \mathrm{~m}^{2}$.
\end{abstract}

Kata Kunci: Herbisida, Ramah Lingkungan, Gulma, Nek’amnaut

\section{Abstract}

Community service has been carried out in the Nek'amnaut farmer group Kiusili village, Timor Tengah Utara district. Dedication was the use of eco-friendly herbicides made from salt, vinegar, water and liquid soap. The dedication method was socialization and demonstration of making and spraying of the solution on weeds. Pre-service and post-service questionnaires were filled to find out farmer group knowledge of herbicides in general and the ability made environmentally friendly herbicides.

The results showed that an eco-friendly herbicide solution has succeeded in killing weeds. Public knowledge changed from the category of not knowing to being well-informed, marked by increased in the knowledge score (SP) from 24 to 76. The percentage of the number of farmer group members who well-informed changed from 0 to $83 \%$. The ability category was change from unable to be very capable of making the herbicide, marked by the ability score (SK) increased from 0 to 83.The number of farmer group members who can make the herbicide increased from 0 to 89\%..The intensity of the use of synthetic herbicides was decreased in the last three years. Five liters of an environmentally friendly herbicide solution killed weed in $48 \mathrm{~m}^{2}$ area.

Keywords:Herbicides, Eco-friendly, Weeds, Nek'amnaut 


\section{PENDAHULUAN}

Gulma bagi petani dan kebanyakan orang yang memiliki hobi bercocok tanam menjadi tumbuhan yang merugikan. Hal ini karena gulma mengganggu proses pertumbuhan tanaman yang ditanam. Gulma yang tumbuh dalam satu media tanam dengan tanaman yang dibudidayakan akan mengakibatkan tanaman tersebut kerdil. Keadaan ini disebabkan karena gulma bersaing dengan tanaman budidaya untuk menyerap nutrisi dari dalam tanah, air dan energi sinar matahari (Rao, 2000). Akar gulma memiliki kecenderungan untuk menjalar dan tumbuh menutupi area tanam sehingga mengurangi ruang tumbuh tanaman. Dengan demikian, tanaman utama lambat bertumbuh, tidak subur dan bahkan mati. Gulma juga dapat menjadi vektor media tumbuhnya penyakit patogen bagi tanaman. Selain itu, gulma mengurangi nilai estetika jika tumbuh di pekarangan rumah atau lahan pertanian.

Para petani Indonesia sudah sejak lama menggunakan beberapa metode untuk menghilangkan gulma atau menguranginya dari lahan pertanian mereka. Beberapa metode di antaranya adalah menyiangi dan mencabut gulma menggunakan peralatan atau secara manual dengan tangan, herbisida dan membakar gulma yang tumbuh. Pembakaran gulma merupakan metode yang sangat beresiko untuk merusak lingkungan dan hutan karena mengakibatkan kebakaran. Penyiangan gulma untuk lahan luas akan membutuhkan banyak tenaga kerja dan peralatan. Penggunaan herbisida adalah solusi bagi petani untuk lahan yang sangat luas. Namun, herbisida yang beredar dan digunakan petani saat ini adalah herbisida sintetis yang disintesis secara kimia misalnya paraquat, glifosat, fosfinositrin yang mana herbisida ini dapat mengganggu keseimbangan ekosistem tanah. Hal ini karena penguraian herbisida yang sangat lama. Penggunaan herbisida-herbisida tersebut secara terus menerusakan membunuh mikroba tanah dan dekomposer lainnya sehingga menyebabkan tanah tidak subur lagi.

Banyak penelitian dalam satu dekade terakhir di Indonesia telah dikembangkan untuk mencari herbisida yang lebih ramah lingkungan dan telah diaplikasikan. Budi dan Hajoeningtijas (2013) telah melakukan penelitian penggunaan herbisida organik ekstrak alang-alanguntuk mengendalikan gulma pada mentimun. Mereka melaporkan bahwa larutan ekstrak gulma alang-alang200 g/l air dapatmenghambat populasi gulma dan menambah jumlah buah dan beratbuah mentimun. Utomo dkk., (2014) telah mengamati pengaruh aplikasi herbisida pra-tanam cuka $\left(\mathrm{C}_{2} \mathrm{H}_{4} \mathrm{O}_{2}\right)$ dibanddingkan dengan glifosat dan paraquat pada gulma tanaman kedelai. Hasil Uji BNT 5\% pada penelitan Utomo dkk., menunjukkan bahwa aplikasi cuka $20 \%$ sebagai herbisida tidak berbeda nyata dibandingkan paraquat $3 \mathrm{~L} \mathrm{ha}^{-1}$ dan glifosat $1 \mathrm{~L} \mathrm{ha}^{-1}$. Talahatudan Papilaya (2015)pemanfaatan ekstrak daun cengkeh (syzygium aromaticum 1.) sebagai herbisida alami terhadap pertumbuhan gulma rumput teki (cyperus rotundus 1.). Mereka melaporkan bahwa peningkatan konsentrasi ekstrak daun cengkeh saat disirampada rumput teki menyebabkan pertumbuhan rumput teki semakin lambat. Budiyanto(2016) telah mengaplikasikan herbisida organik di kelompok tani Sumber Urip-1 DesaWonorejo Kecamatan Poncokusumo Kabupaten Malang. Frastika dkk.,(2017) telah mengamati bawah daun sufmuti (kirinyuh) efektif untuk menghambat pertumbuhan gulma karena metabolit sekundernya. Budiyanto (2017) telah mengamati bahwa banyak sekali tanaman lokal yang berpotensi digunakan sebagai herbisida organik.

Masyarakat Kabupaten Timor Tengah Utara khususnya masyarakat Desa Kiusili Kecamatan Bikomi Selatan sebagian besar adalah petani dan mereka memiliki akses yang 
terbatas terkait kemajuan ilmu pengetahuan, informasi dan teknologi. Oleh sebab itu, penggunaan herbisida ramah lingkungan belum banyak diketahui dan hingga saat ini masih menggunakan herbisida sintetis. Beberapa bahan yang mudah didapat dan berpotensi meracuni gulma adalah sabun cair (sunlight), garam dapur dan cukaasam. Sabun cair berfungsi sebagai surfaktan untuk membasahi seluruh permukaan tumbuhan. Garam dapur dan asam dapat masuk melalui pori - pori jaringan tumbuhan gulma dan mengganggu metabolism gulma. Bahan - bahan tersebut mudah terurai di lingkungan dibandingkan herbisida sintetis sehingga tidak merusak ekosistem tanah. Beberapa waktu kemudian gulma akan mengering. Berdasarkan uraian tulisan ini maka pengabdi tertarik melakukan pengabdian masyarakat tentang penggunaan herbisida ramah lingkungan berbahan sabun cair, cuka asam dan garam dapur di Desa Kiusili.

Tujuan dari kegiatan pengabdian pada masyarakat ini adalah masyarakat memperoleh pengetahuan dan informasi tentang herbisida,masyarakat memiliki keterampilan dalam membuat dan mengaplikasikan herbisida ramah lingkungan di desanya, meminimalisir penggunaan herbisida sintetik.

\section{METODE}

\section{Tempat dan Waktu Pengabdian}

Waktu pelaksanaan kegiatan adalah selama satu tahun anggaran yaitu selama tahun 2019 . Kegiatan terbagi menjadi beberapa tahap dan secara garis besar terbagi menjadi 4 tahap. Tahapan tersebut meliputi tahap adalah 1 pra pengabdian (pre eliminary work) pada tanggal 28 Juni - 6 Agustus 2019, tahap 2 adalah tahap survey, persiapan bahan dan alat, dan diskusi dengan kepala desa dan kelompok tani tujuan yaitu tanggal 8 - 23 Agustus 2019, tahap 3 adalah pelaksanaan, tindak lanjut dan evaluasi kegiatan tanggal 24 Agustus - 5 Oktober 2019, tahap 4 adalah penyusunan laporan akhir, seminar dan publikasi yang diselesaikan pada bulan oktober 2019 ini. Tahap 3 yaitu pelaksanaan juga terbagi menjadi 6 kali kunjungan meliputi kunjungan 1 bertujuan untuk sosialisasi dan demo pembuatan larutan herbisida ramah lingkungan; kunjungan 2 - 5 adalah tahap tindak lanjut berupa pengamatan dan pendampingan; kunjungan ke 6 adalah pengambilan data akhir dan evaluasi kegiatan pengabdian tentang aplikasi herbisida ramah lingkungan ini dilaksanakan di Desa Kiusili, Kecamatan Bikomi Selatan, Kabupaten Timor Tengah Utara, Propinsi Nusa Tenggara Timur.

\section{Alat}

Peralatan yang digunakan pada kegiatan praktek pengabdian ini adalah tabung atau tanki semprot, gayung 1 liter, gelas ukur 1 liter, timbangan, pengaduk kayu, ember, corong besar, sarung tangan, masker.

\section{Bahan}

Bahan yang digunakan adalah sabun cair sunlight, garam, cuka asam, dan air.

\section{Tahap Pengabdian}

Tahap 1 Pre eliminary work pra pengabdian 
Tim pengabdi pada tahap ini melakukan kerja pendahuluan di mana larutan herbisida dibuat dan disemprotkan pada rumput untuk melihat dampaknya terhadap kerusakan gulma. Kegiatan ini dilaksanakan selama 37 hari.

\section{Tahap 2 Survey dan persiapan}

Tim pengabdi pada tahap ini melakukan survey ke desa tujuan, pertemuan dengan bapak kepala desa dan juga kelompok tani. Pertemuan ini membahas dan menetapkan waktu dan lokasi kebun masyarakat untuk pelaksanaan kegiatan, serta hal - hal teknis yang dibutuhkan dalam kegiatan. Di samping itu, Tim pengabdi juga mempersiapkan bahan, alat dan materi serta soal-soal kuisioner untuk pelaksanaan pengabdian. Kegiatan ini dilaksanakan selama 16 hari.

\section{Tahap 3 pelaksanaan kegiatan kunjungan}

Kunjungan 1 : sosialisasi dan demo kegiatan

Pada tahap ini, tim pengabdi melakukan perkenalan. Selanjutnya, masyarakat mengisi kuisioner yang telah disediakan tim pengabdi. Kuisioner ini bertujuan agar tim peneliti memperoleh data awal tentang pengetahuan dan keterampilan masyarakat terkait penggunaan herbisida sintetis dibandingkan dengan herbisida ramah lingkungan.Kegiatan sosialisasi dilakukan setelah pengambilan data kuisioner. Kegiatan ini dilakukan dengan cara diskusi serta pembagian leaflet herbisida ramah lingkungan. Setelah itu, dilakukan juga demo pembuatan herbisida tersebut serta penyemprotannya terhadap gulma sekitar kebun masyarakat. Kegiatan ini dilaksanakan selama 1 hari.

Kunjungan 2 : Pengamatan perlakuan kunjungan 1

Kegiatan ini adalah pengamatan terhadap rumput yang telah disemprot pada kunjungan 1. Pengamatan dilakukan 5 hari pasca penyemprotan dengan lama kegiatan 1 hari.

Kunjungan 3 : Pendampingan masyarakat tentang pembuatan dan aplikasi.

Tahap ini adalah tahap tindak lanjut di mana anggota kelompok tani dilatih untuk membuat dan menyemprotkan larutan herbisida ramah lingkungan ini secara mandiri. Kegiatan ini dilaksanakan 2 hari pasca kunjungan ke 2 dengan lama waktu pekerjaan 1 hari.

Kunjungan 4 : Tindak lanjut pendampingan kunjungan ke 3.

Pada kunjungan ke 4 bertujuan mengamati dan mendampingi masyarakat yang telah menerapkan informasi dan latihan tentang herbisida yang diperoleh pada lahannya. Selain itu juga diamati hasil penyemprotan pada kunjungan ke 3 . Kegiatan dilaksanakan 5 hari setelah kunjungan ke 3 dengan lama waktu kegiatan 1 hari.

Kunjungan 5 : Pengamatan penerapan kunjungan ke 4.

Pada kegiatan ini diamati hasil aplikasi anggota kelompok tani pada salah satu kebun warga. Kegiatan dilaksanakan 7 hari pasca kunjungan 4 dengan lama waktu 1 hari. Luas area lahan yang disemprot juga diukur.

Kunjungan 6 : Pengisian kuisioner post pengabdian dan evaluasi.

Kegiatan ini dilaksanakan pada hari sabtu tanggal 5 oktober 2019. Kegiatan ini bertujuan memperoleh informasi terkait pengetahuan dan keterampilan tentang 
herbisida pasca penerapan pengabdian, sekaligus menjadi evaluasi bagi tim pengabdi dan mitra.

\section{Tahap 4 Penyusunan laporan akhir}

Kegiatan tahap 4 merupakan kegiatan tahap akhir, yang meliputi penyusunan laporan akhir, seminar dan publikasi artikel pengabdian. Kegiatan ini dilaksanakan pada bulan oktober 2019.

\section{Peserta dan Pelaksana}

Peserta kegiatan adalah anggota kelompok tani Nek'amnaut, sedangkan pelaksana kegiatan adalah dosen - dosen Fakultas Pertanian Universitas Timor dibantu oleh mahasiswa - mahasiswa prodi kimia Faperta Unimor.

\section{Prosedur Kerja Pembuatan Herbisida Ramah Lingkungan}

Adapun prosedur kerja preparasi herbisida ini yaitu:

- Tuangkan $2 \mathrm{~kg}$ garam dalam ember yang berisikan5 Liter air.

- Tambahkan cuka asam 1 liter ke dalam ember.

- Masukan sabun cair sebanyak 800 mL ke dalam ember tersebut dan diaduk.

- Tambahkan 5 liter air ke dalam larutan dan aduk sampai rata.

- Larutan tersebut dimasukan dalam alat semprot untuk disemprotkan pada gulma.

- Amati gulma yang disemprot setelah beberapa waktu kemudian.

\section{Teknik Pengolahan Data}

Data yang diperoleh berupa data kualitatif dan data kuantitatif. Data kualitatif adalah hasil pengamatan aplikasi penyemprotan gulma oleh herbisida pada pengabdian ini. selain itu, diperoleh dokumentasi berlangsungnya kegiatan pengabdian. Data kuantitatif diperoleh dari data quisioner 1 dan quisioner 2. Quisioner 1 dilakukan pra sosialisasi dan quisioner 2 dilakukan setelah seluruh rangkaian kegiatan pengabdian di desa. Jumlah soal quisioner 1 adalah 8 nomor dan quisioner 2 adalah 20 nomor. Quisioner 2 telah dikelompokkan menjadi beberapa tiga bagian yaitu bagian I adalah SP, bagian II adalah SK dan bagian III adalah Penggunaan pestisida oleh masyarakat.

Pengolahan hasil jawaban atas pertanyaan quisioner 1akan diperoleh data tingkat pengetahuan masyarakat terhadap herbisida umumnya (SP), tingkat kemampuan membuat herbisida ramah lingkungan (SK), intensitas penggunaan herbisida sintetik (IHS). Data SP tertuang dalam soal nomor 1, 3, 4,5 dan 8; data SK tertuang dalam soal nomor 6, 7; dan data IHS tertuang soal nomor 2. Pada SP dan SK, Setiap opsi jawaban pilihan ganda memiliki nilai yaitu $\mathrm{a}=$ tidak tahu $=0, \mathrm{~b}=1, \mathrm{c}=2, \mathrm{~d}=3$. Skor diperoleh menggunakan rumus berikut:

$$
\mathrm{SP}=\frac{\mathrm{E}}{\mathrm{f}} \times 100 \quad \text { dan } \quad \mathrm{SK}=\frac{\mathrm{r}}{\mathrm{h}} \times 100
$$

Di mana :

$\mathrm{e}=$ jumlah total nilai pilihan ganda dari jawaban responden pada bagian soal $\mathrm{sp}$

$\mathrm{f}=$ total nilai tertinggi seluruh jawaban untuk bagian soal $\mathrm{sp}$

$\mathrm{g}=$ jumlah total nilai pilihan ganda dari jawaban responden pada bagian soal sk

$\mathrm{h}=$ total nilai tertinggi seluruh jawaban untuk bagian soal sk

karena jumlah soal SP adalah 5 nomor dengan total nilai tertinggi berada pada opsi d yaitu 3 maka nilai $\mathrm{f}=5 \times 3=15$. Sedangkan pada soal SK sebanyak 2 soal sehingga nilai $\mathrm{h}=2 \times 3=$ 6. Dengan memasukan nilai f dan h maka persamaan (1) menjadi : 


$$
\mathrm{SP}=\frac{\mathrm{E}}{1} \times 100 \quad \text { dan } \quad \mathrm{SK}=\frac{\underline{\underline{\underline{G}}}}{6} \times 100
$$

Jawaban quisioner 2 hampir sama dengan quisioner 1 dapat dikelompokkan menjadi beberapa kelompok data dengan sedikit perluasan. Data yang dapat diperoleh adalah tingkat pengetahuan masyarakat terhadap herbisida umumnya (SP), tingkat kemampuan membuat herbisida ramah lingkungan (SK), intensitas penggunaan herbisida sintetik (IHS), intensitas penggunaan herbisida ramah lingkungan (IHRL), alasan tidak menggunakan herbisida sintetik hingga saat ini (ATIHS), alasan ingin menggunakan herbisida ramah lingkungan (IHRL). Data SP tertuang dalam soal nomor 1, 3, 4,5 dan 8; data SK tertuang dalam soal nomor 6, 7; dan data IHS tertuang soal nomor 2. Pada SP dan SK, Setiap opsi jawaban pilihan ganda memiliki nilai yaitu $\mathrm{a}=\operatorname{tidak}$ tahu $=0, \mathrm{~b}=1, \mathrm{c}=2, \mathrm{~d}=3$. Skor diperoleh menggunakan rumus berikut:

$$
\mathrm{SP}=\frac{\mathrm{l}}{\mathrm{j}} \mathrm{x} 100 \quad \text { dan } \quad \mathrm{SK}=\frac{\mathrm{K}}{\mathrm{l}} \times 100
$$

Di mana :

$\mathrm{i}=$ jumlah total nilai pilihan ganda dari jawaban responden pada bagian soal $\mathrm{sp}$

$\mathrm{j}=$ total nilai tertinggi seluruh jawaban untuk bagian soal sp

$\mathrm{k}=$ jumlah total nilai pilihan ganda dari jawaban responden pada bagian soal sk

$1=$ total nilai tertinggi seluruh jawaban untuk bagian soal sk

karena jumlah soal SP sebanyak 6 nomor dengan total nilai tertinggi berada pada opsi d yaitu 3 maka nilai $\mathrm{j}=6 \times 3=18$. Sedangkan pada soal SK sebanyak 7 soal sehingga nilai $1=7 \times 3$ $=21$. Dengan memasukan nilai $\mathrm{f}$ dan $\mathrm{h}$ maka persamaan (1) menjadi :

$$
\mathrm{SP}=\frac{1}{1} \times 100 \quad \text { dan } \quad \mathrm{SK}=\frac{\mathrm{K}}{\mathrm{z}} \times 100
$$

Data IHS dan IHRL pada quisioner 2 lebih rinci yaitu dikelompokkan berdasarkan waktu yaitu penggunaan herbisida sintetik saat 3 tahun yang lalu (TS-2), penggunaan herbisida sintetik saat 2 tahun yang lalu (TS-1), penggunaan herbisida sintetik pada tahun saat ini (TS). Nilai SP dan SK setelah diperoleh dapat dikategorikan ke dalam 5 tingkat dengan range nilai indeks skor tertentu yang dirangkum dalam Tabel 1.

Tabel 1 indeks skor tingkat SP atau SK masyarakat

\begin{tabular}{|l|l|}
\hline Skor & kategori \\
\hline $80-100$ & Sangat tahu / sangat mampu / sangat baik \\
\hline $70-79$ & Tahu / mampu / baik \\
\hline $60-69$ & Cukup tahu / sedang / cukup mampu \\
\hline $50-59$ & Kurang tahu / kurang mampu \\
\hline$<50$ & Tidak tahu/ tidak mampu \\
\hline
\end{tabular}

\section{HASIL DAN PEMBAHASAN}

Hasil 
Tahap 1 Pre eliminary work pra pengabdian

a. Pre eliminary work:

Pembuatan dan penyemprotan larutan herbisida ramah lingkungan tahap uji coba. Hasil pengamatan menunjukkan bahwa rumput benar - benar mati setelah 4 - 9 hari (gambar $1)$.
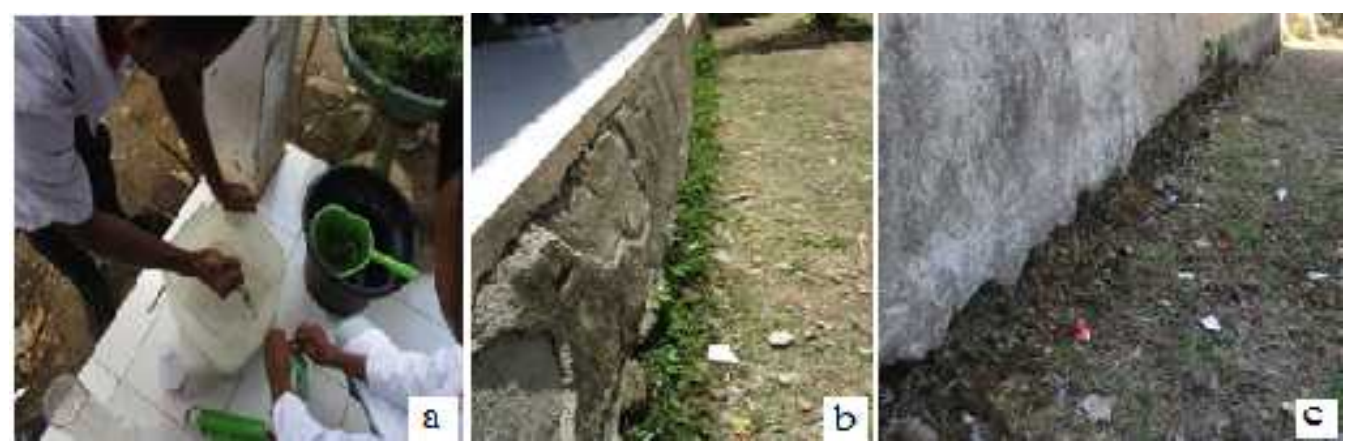

Gambar 1. a) pembuatan larutan herbisida, b) gulma di tepi tembok sebelum disemprot, c) gulma tersebut 5 hari setelah disemprot.

\section{Tahap 2 Survey dan Persiapan}

Kegiatan ini dilakukan pada kamis, 8 Agustus 2019. Pada kegiatan ini bapak desa dan kelompok tani setuju untuk dilaksanakan kegiatan pengabdian dan disepakati waktu kegiatannya yaitu tanggal 20 Agustus 2019. Namun, karena beberapa kendala sehingga kegiatannya dilaksanakan pada tanggal 24 Agustus 2019. Survey ini disajikan dalam gambar 2.a.
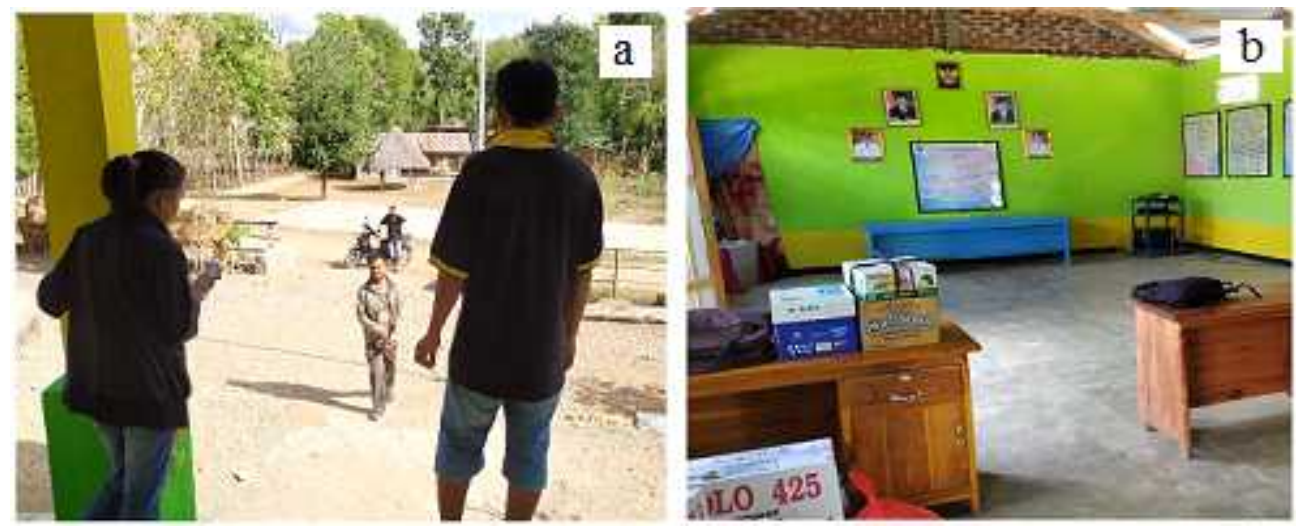

Gambar 2.a) Survey, b) Persiapan

Persiapan dilaksanakan pada hari kamis 22 Agustus 2019 meliputi pengumpulan alat dan bahan meliputi garam, cuka, sabun cair, tangki sprayer, ember, gayung, gelas ukur 1 liter, timbangan (gambar 2 b). Penyusunan dan perbanyakanleaflet, quisioner dan daftar hadir kegiatan, serta penyediaan snack untuk kegiatan hari sabtu dilaksanakan pada hariJumat, 23 Agustus 2019.

\section{Tahap 3 pelaksanaan kegiatan kunjungan}


Kunjungan 1 : sosialisasi dan demo kegiatan dilaksanakan 1 hari yaitu pada hari sabtu 24 Agustus 2019. Kegiatan ini diawali dengan pengisian quisioner oleh masyarakat. Kuisioner ini berisikan 8 pertanyaan yang hasilnya diolah dan dirangkum pada Tabel 2. Selanjutnya kegiatan sosialisasi dilakukan dengan cara ceramah, diskusi dan dibantu dengan leaflet yang dibagikan (Gambar 3.a). Kegiatan berikutnya adalah demo pembuatan dan penyemprotan herbisida ini (gambar 3.b).

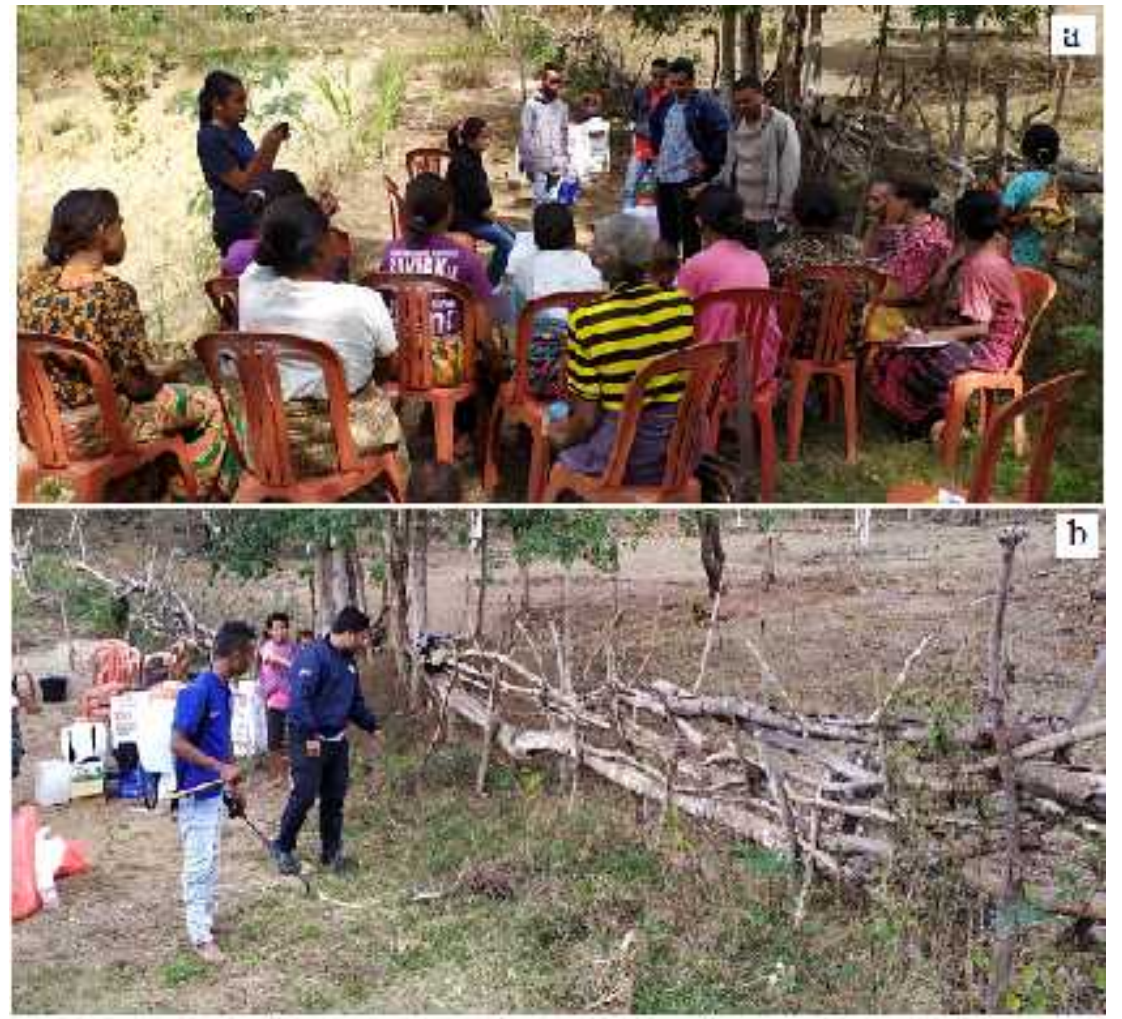

Gambar 3. a) Pengisian quisioner, sosialisasi, diskusi; b) demo pembuatan dan penyemprotan larutan herbisida ramah lingkungan.

Kunjungan 2 : Pengamatan perlakuan kunjungan 1 di mana rumput sudah kering pada Kamis 29 Agustus 2019 (Gambar 4)

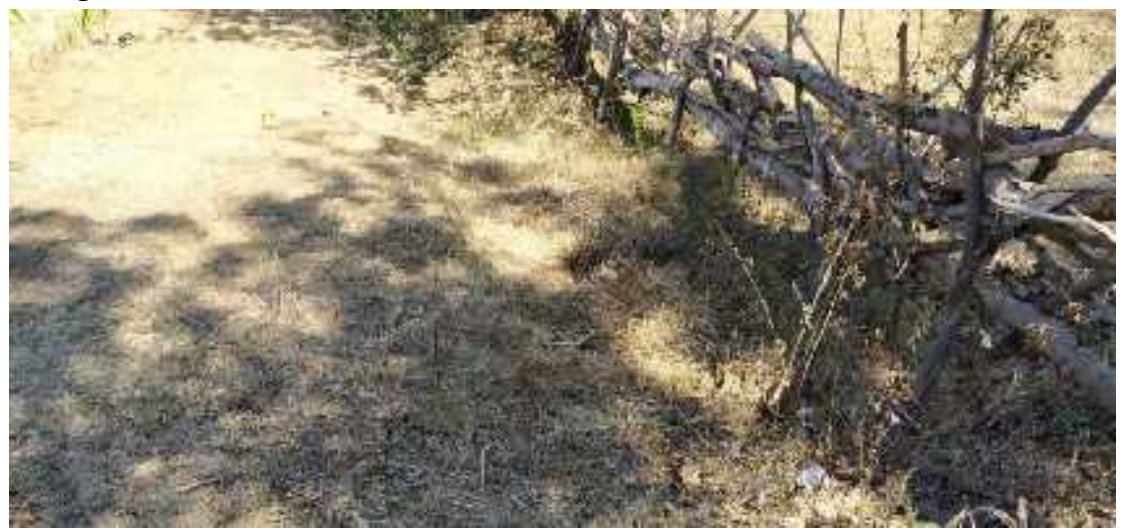

Gambar 4.Rumput yang disemprot pada kunjungan 1 menjadi kering.

Kunjungan 3: Kegiatan pendampingan dilaksanakan pada sabtu 31 Agustus dan teramati beberapa anggota kelompok tani telah mengetahui dan mampu secara mandiri 
membuat larutan herbisida ini serta telah menyemprotkannya pada area yang masih ditumbuhi rumput (gambar 5)
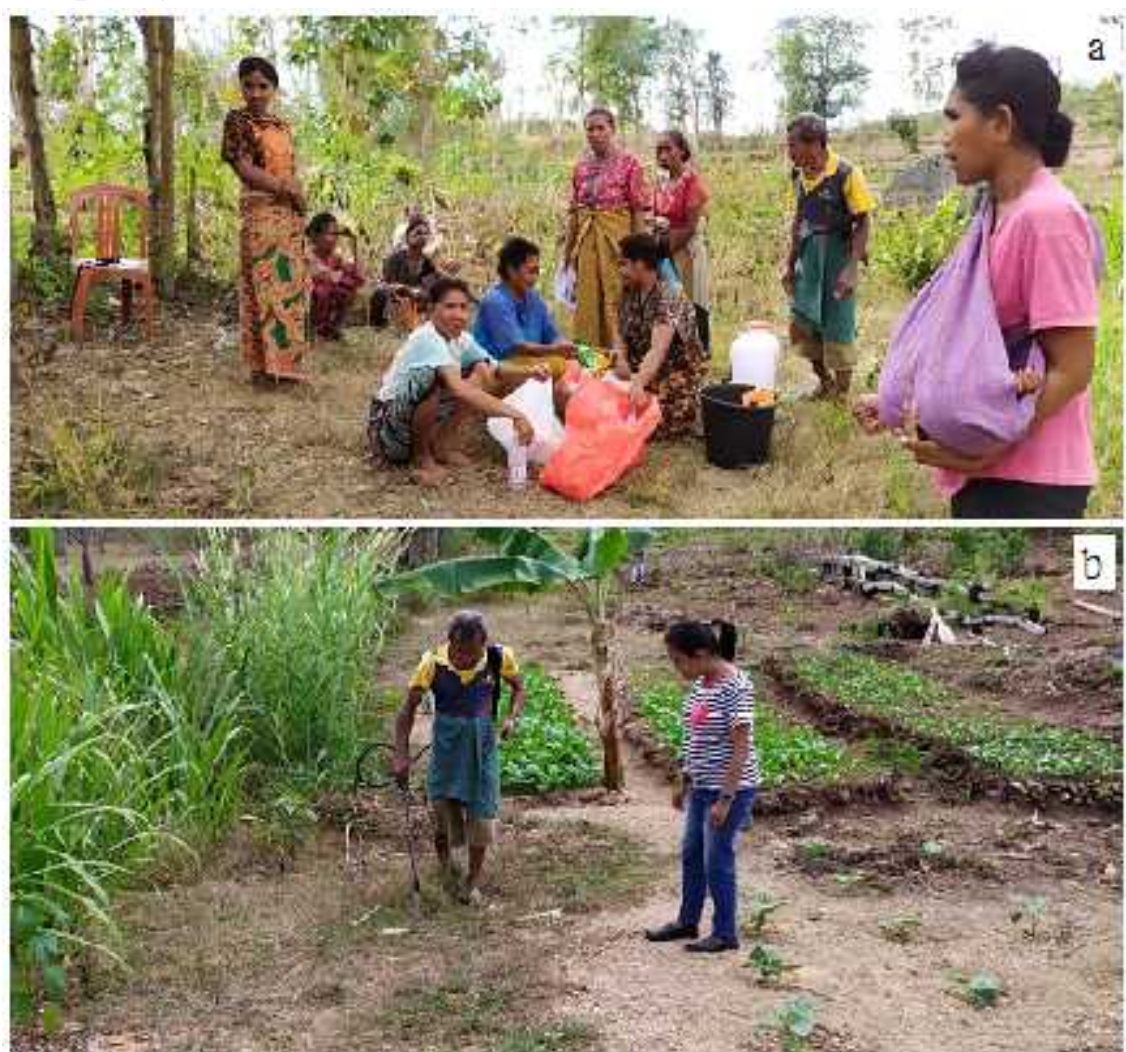

Gambar 5. a) Masyarakat membuat larutan herbisida ramah lingkungan. b) Masyarakat menyemprotkan larutan herbisida ini pada rumput.

Kunjungan 4 : Kunjungan ini dilaksanakan pada 5 september 2019 untuk mengamati hasil semprotan padakunjungan ke 3 (gambar 6)
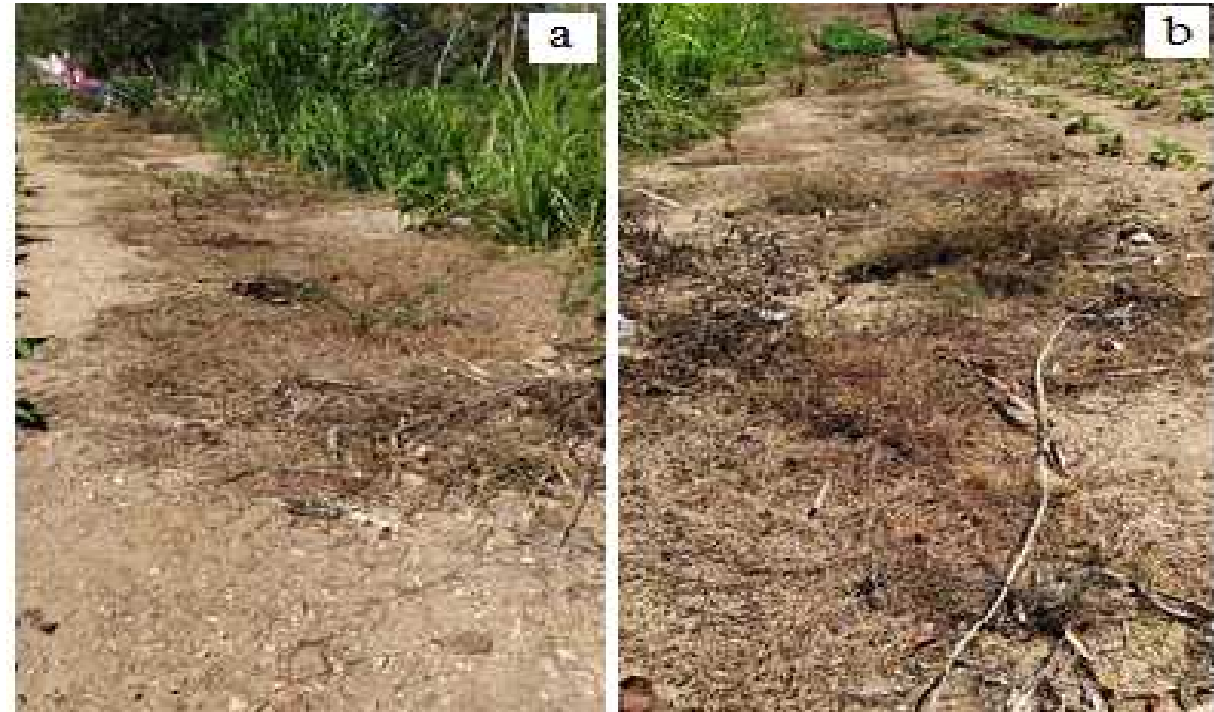

Gambar 6. Penampakan gulma yang telah kering a) dilihat dari depan; b) dilihat dari belakang.

Jumlah warga yang mengaplikasikan ke lahannya adalah sebanyak 2 orang saat itu dan beberapa warga sedang membuat herbisida ini untuk disemprotkan. Jumlah yang 
telah mengetahui cara membuat larutan tersebut sampai saat itu adalah sebanyak 13 orang berdasarkan pengamatan (Gambar 7)

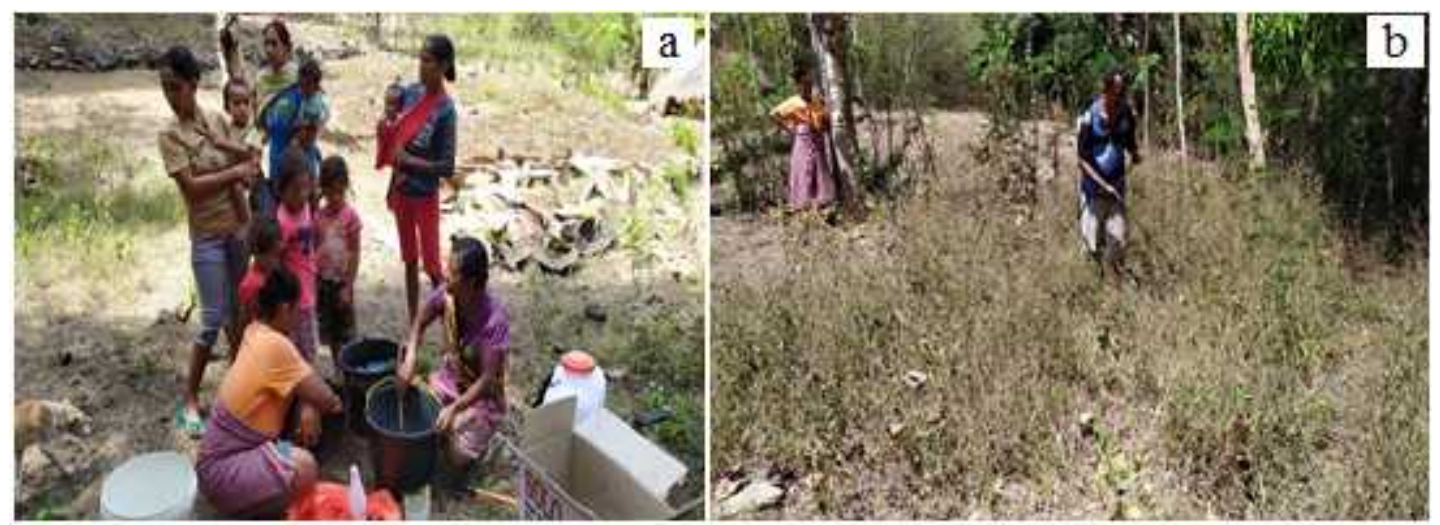

Gambar 7 a) Masyarakat membuat larutan herbisida ramah lingkungan secara mandiri b) Masyarakat mengaplikasikan larutan ini pada kebun mereka.

Kunjungan 5 : Pengamatan gulma yang disemprot pada penerapan kunjungan ke 4. Kunjungan 5 dilaksanakan pada kamis 12 september 2019 dan diperoleh data bahwa sebanyak 5 liter larutan dapat membunuh gulma dengan luas area $48 \mathrm{~m}^{2}$ atau berukuran panjang $\mathrm{x}$ lebar $=6,92 \times 6,92 \mathrm{~m}^{2}($ gambar 8$)$

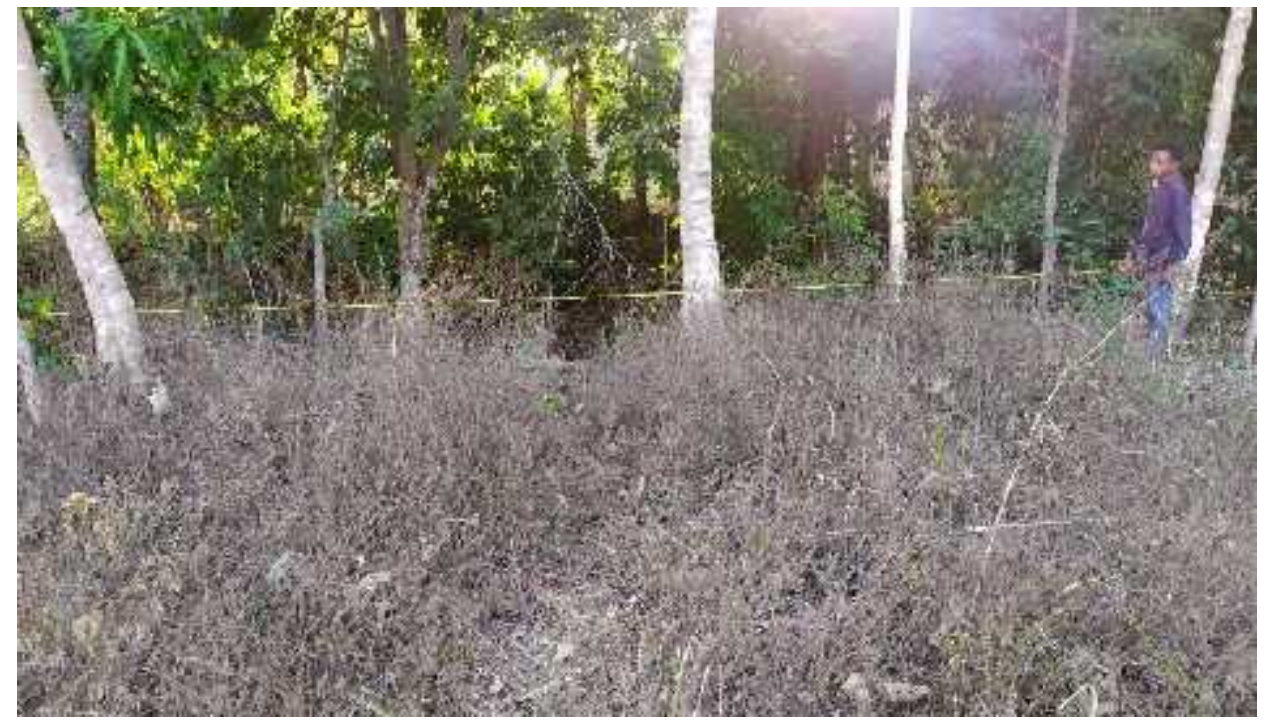

Gambar 8. Pengukuran luas area lahan berisi gulma yang kering.

Kunjungan 6 : Pengisian quisioner post pengabdian dan evaluasi (gambar 9.a).Kegiatan ini telah dilaksanakan pada hari sabtu tanggal 5 oktober 2019. Kegiatan ini juga diakhiri dengan penyerahan barang pengabdian kepada kelompok tani Nek'amnaut (gambar 9.b). kegiatan perpisahan didokumentasikan dalam gambar 9.c. Pertanyaan dalam quisioner ke 2 ini lebih banyak yaitu 20 pertanyaan dengan tujuan agar menggali pemahaman yang lebih dalam terkait sosialisasi dan aplikasi pengabdian ini. Hasil jawaban dari Quisioner 2 diolah dan dirangkum dalam Tabel 3. 


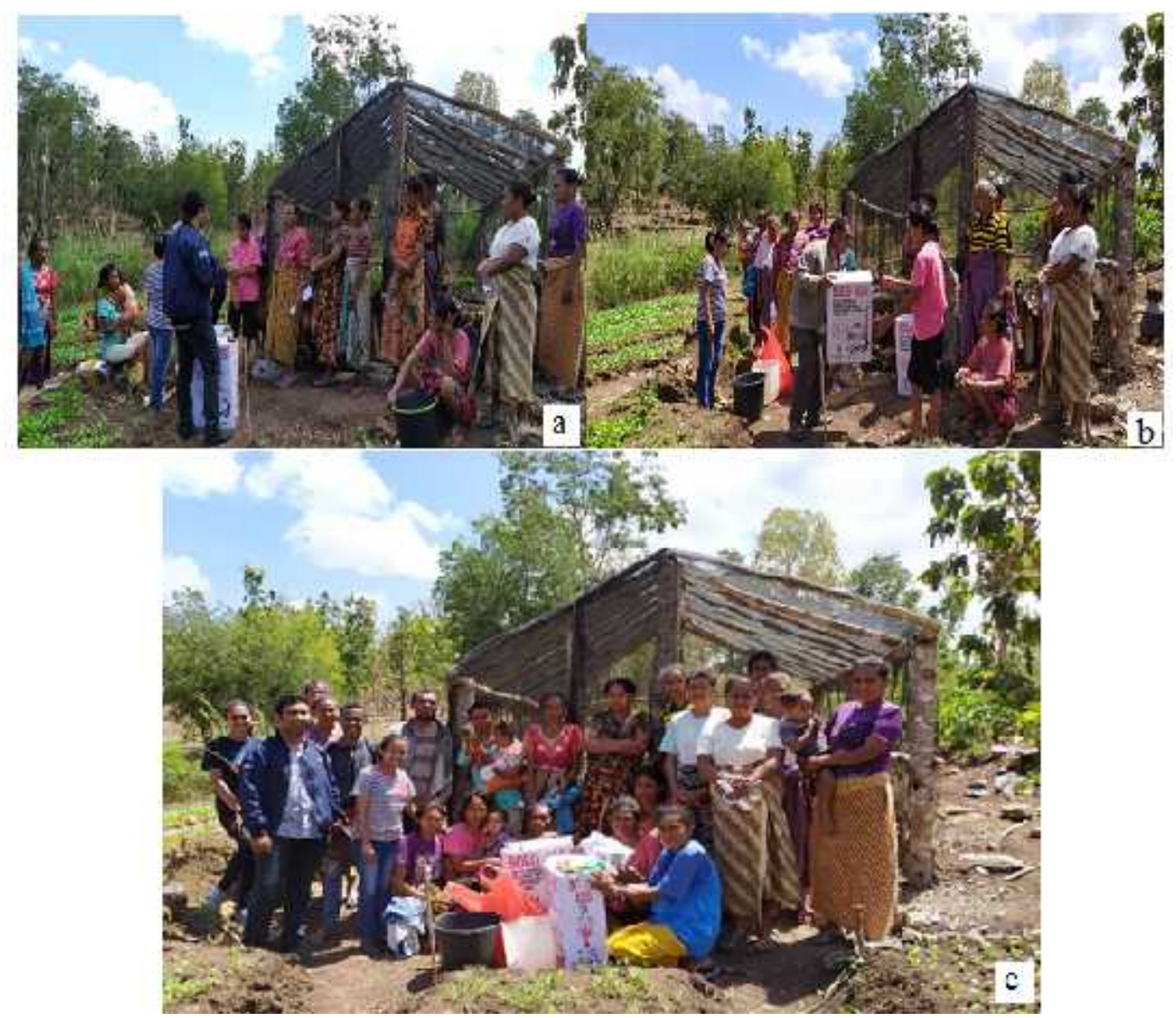

Gambar 9. a) Pengisian quisioner 2, b) penyerahan barang, c) perpisahan dengan warga

Tabel 2. Data pengisian Quisioner 1

\begin{tabular}{|l|l|c|c|c|c|}
\hline No & Nama & SP & SK & IHS & IHR \\
\hline 1 & Responden 1 & 33 & 0 & 1 & 0 \\
\hline 2 & Responden 2 & 33 & 0 & 1 & 0 \\
\hline 3 & Responden 3 & 0 & 0 & 0 & 0 \\
\hline 4 & Responden 4 & 33 & 0 & 1 & 0 \\
\hline 5 & Responden 5 & 33 & 0 & 0 & 0 \\
\hline 6 & Responden 6 & 33 & 0 & 1 & 0 \\
\hline 7 & Responden 7 & 40 & 0 & 1 & 0 \\
\hline 8 & Responden 8 & 33 & 0 & 1 & 0 \\
\hline 9 & Responden 9 & 33 & 0 & 1 & 0 \\
\hline 10 & Responden 10 & 0 & 0 & 0 & 0 \\
\hline 11 & Responden 11 & 0 & 0 & 0 & 0 \\
\hline 12 & Responden 12 & 0 & 0 & 0 & 0 \\
\hline 13 & Responden 13 & 0 & 0 & 0 & 0 \\
\hline 14 & Responden 14 & 27 & 0 & 0 & 0 \\
\hline 15 & Responden 15 & 27 & 0 & 0 & 0 \\
\hline 16 & Responden 16 & 33 & 0 & 1 & 0 \\
\hline 17 & Responden 17 & 33 & 0 & 1 & 0 \\
\hline 18 & Responden 18 & 47 & 0 & 1 & 0 \\
\hline \multicolumn{2}{|l|}{ Total } & 438 & 0 & 10 & 0 \\
\hline Rata - rata & 24 & 0 & 0,5 & 0 \\
\hline
\end{tabular}


Keterangan: SPH = Skor pengetahuan tentang herbisida pada umumnya termasuk dampak positif dan negatifnya; SK : Skor Kemampuan membuat herbisida ramah lingkungan; IHS: Intensitas menggunakan herbisida sintetik, IHR : intensitas menggunakan herbisida ramah lingkungan.

Tabel 3. Data pengisian Quisioner 2

\begin{tabular}{|c|c|c|c|c|c|c|c|c|c|}
\hline \multirow[t]{2}{*}{ No } & \multirow[t]{2}{*}{ Nama } & \multirow[t]{2}{*}{$\overline{\mathrm{SP}}$} & \multirow[t]{2}{*}{ SK } & \multicolumn{3}{|l|}{ IHS } & \multicolumn{3}{|l|}{ IHS } \\
\hline & & & & TS-2 & TS-1 & TS & TS-2 & TS-1 & TS \\
\hline 1 & Responden 1 & 94 & 100 & 1 & 0 & 0 & 0 & 0 & 1 \\
\hline 2 & Responden 2 & 83 & 67 & 1 & 0 & 0 & 0 & 0 & 0 \\
\hline 3 & Responden 3 & 89 & 86 & 0 & 0 & 0 & 0 & 0 & 0 \\
\hline 4 & Responden 4 & 94 & 95 & 0 & 0 & 1 & 0 & 0 & 1 \\
\hline 5 & Responden 5 & 50 & 71 & 0 & 0 & 0 & 0 & 0 & 0 \\
\hline 6 & Responden 6 & 94 & 100 & 1 & 0 & 0 & 0 & 0 & 1 \\
\hline 7 & Responden 7 & 94 & 95 & 0 & 1 & 0 & 0 & 0 & 1 \\
\hline 8 & Responden 8 & 94 & 100 & 1 & 0 & 0 & 0 & 0 & 1 \\
\hline 9 & Responden 9 & 67 & 86 & 1 & 0 & 0 & 0 & 0 & 0 \\
\hline 10 & Responden 10 & 77 & 71 & 0 & 0 & 0 & 0 & 0 & 0 \\
\hline 11 & Responden 11 & 67 & 71 & 0 & 0 & 0 & 0 & 0 & 0 \\
\hline 12 & Responden 12 & 44 & 95 & 0 & 0 & 0 & 0 & 0 & 0 \\
\hline 13 & Responden 13 & 83 & 86 & 0 & 0 & 0 & 0 & 0 & 0 \\
\hline 14 & Responden 14 & 61 & 100 & 0 & 0 & 0 & 0 & 0 & 0 \\
\hline 15 & Responden 15 & 67 & 95 & 0 & 0 & 0 & 0 & 0 & 0 \\
\hline 16 & Responden 16 & 94 & 91 & 0 & 1 & 0 & 0 & 0 & 1 \\
\hline 17 & Responden 17 & 56 & 38 & 0 & 1 & 0 & 0 & 0 & 0 \\
\hline 18 & Responden 18 & 61 & 52 & 0 & 1 & 0 & 0 & 0 & 0 \\
\hline \multicolumn{2}{|c|}{ Total } & 1369 & 1499 & 5 & 4 & 1 & 0 & 0 & 5 \\
\hline \multicolumn{2}{|c|}{ Rata - rata } & 76 & 83 & 0,27 & 0,22 & 0,05 & 0 & 0 & 0,28 \\
\hline
\end{tabular}

\section{Tahap 4 Penyusunan laporan akhir}

Kegiatan tahap 4 yaitu pengumpulan data, pembahasan dan penyusunan laporan akhir, seminar dan publikasi artikel pengabdian. Kegiatan ini telah dilaksanakan pada bulan oktober 2019.

\section{Pembahasan}

\section{Tingkat pengetahuan dan kemampuan membuat herbisida ramah lingkungan}

Kegiatan sosialisasi berlangsung dengan baik dan masyarakat antusias dalam setiap proses kegiatan ini. Hasil pengisian quisioner 1 dan 2 oleh masyarakat telah diolah dan ditampilkan dalam Tabel 2 dan 3. Walaupun demikian data mentah jawaban quisioner 1 dan 2 telah dilampirkan dalam lampiran. Tabel 2 dan 3 dapat dibandingkan dan dirangkum menjadi Tabel 4 untuk mendapatkan data dampak kegiatan yang dilakukan terhadap pengetahuan dan kemampuan masyarakat untuk menghasilkan herbisida ramah lingkungan dalm pengabdian ini secara mandiri.

Tabel 4. Perbandingan SP dan SK quisioner 1 dan quisioner 2

\begin{tabular}{|l|l|l|l|}
\hline No & Nama & SP & SK \\
\hline
\end{tabular}




\begin{tabular}{|l|l|c|c|c|c|}
\hline & & Q 1 & Q 2 & Q 1 & Q 2 \\
\hline 1 & Responden 1 & 33 & 94 & 0 & 100 \\
\hline 2 & Responden 2 & 33 & 83 & 0 & 67 \\
\hline 3 & Responden 3 & 0 & 89 & 0 & 86 \\
\hline 4 & Responden 4 & 33 & 94 & 0 & 95 \\
\hline 5 & Responden 5 & 33 & 50 & 0 & 71 \\
\hline 6 & Responden 6 & 33 & 94 & 0 & 100 \\
\hline 7 & Responden 7 & 40 & 94 & 0 & 95 \\
\hline 8 & Responden 8 & 33 & 94 & 0 & 100 \\
\hline 9 & Responden 9 & 33 & 67 & 0 & 86 \\
\hline 10 & Responden 10 & 0 & 77 & 0 & 71 \\
\hline 11 & Responden 11 & 0 & 67 & 0 & 71 \\
\hline 12 & Responden 12 & 0 & 44 & 0 & 95 \\
\hline 13 & Responden 13 & 0 & 83 & 0 & 86 \\
\hline 14 & Responden 14 & 27 & 61 & 0 & 100 \\
\hline 15 & Responden 15 & 27 & 67 & 0 & 95 \\
\hline 16 & Responden 16 & 33 & 94 & 0 & 91 \\
\hline 17 & Responden 17 & 33 & 56 & 0 & 38 \\
\hline 18 & Responden 18 & 47 & 61 & 0 & 52 \\
\hline \multicolumn{2}{|l|}{ Total } & 438 & 1369 & 0 & 1499 \\
\hline Rata-rata & 24 & 76 & 0 & 83 \\
\hline
\end{tabular}

Keterangan : $\mathrm{SP}=$ skor pengetahuan, $\mathrm{SK}=$ Skor kemampuan membuat herbisida ramah lingkungan, Q1 = quisioner 1 sebelum sosialisasi, Q2 = quisioner 2 setelah sosialisasi.

Berdasarkan Tabel 4 teramati bahwa pengetahuan dan kemampuan anggota kelompok tani Nek'amnaut meningkat setelah kegiatan pengabdian ini. Peningkatan pengetahuan ditandai oleh bertambahnya nilai rata-rata SP yaitu 24 menjadi 76 sedangkan kemampuan masyarakat meningkat dari rata-rata SK 0 menjadi 83. Dengan demikian, setelah pengabdian ini masyarakat telah memiliki pengetahuan terkait herbisida pada umumnya dan kemampuan membuat herbisida ramah lingkungan masing - masing dengan kategori baik dan katagori sangat mampu. Selain itu, teramati bahwa presentase jumlah warga yang memiliki pengetahuan dengan kategori cukup tahu hingga sangat tahu meningkat dari $0 \%$ menjadi 83\% dari jumlah anggota kelompok tani setelah kegiatan ini. Presentase ini diperoleh dengan membandingkan jumlah anggota kelompok tani yang mendapat nilai SP > 60 terhadap jumlah keseluruhan anggota kelompok tani dikali dengan $100 \%$, yaitu 15 orang/18 orang $\mathrm{x}$ $100 \%$. Sementara itu dengan cara yang sama untuk nilai SK maka diperoleh presentasi jumlah warga yang memiliki kemampuan membuat herbisida ramah lingkungan dari $0 \%$ menjadi $89 \%$ dari total anggota kelompok tani.

\section{Aplikasi herbisida ramah lingkungan}

Herbisida ramah lingkungan ini beraroma asam cuka dan berwarna putih keruh sebelum ditambahkan sabun cair. Herbisida ini berwarna hijau setelah ditambahkan sabun cair dan tetap beraroma cuka. Aroma ini tidak akan hilang dalam sehari kecuali jika tersapu air hujan.

Herbisida ramah lingkungan ini, dalam aplikasi penyemprotannya, berhasil menampilkan kemampuan untuk membunuh gulma. Hal ini teramati dari proses kerusakan bertahap pada gulma mulai dari dehidrasi gulma, layu sampai kering dan akhirnya mati. Dehidrasi ditandai dengan menghitamnya rumput dengan semakin nampak butiran garam yang menempel pada rumput. Dehidrasi kemudian diikuti dengan layunya gulma dan lama 
kelamaan menjadi kering. Gulma tersebut akan mati karena kekeringan dan panasnya sinar matahari. Aroma asam cuka saat penyemprotan tidak hilang sampai larutan ini benar - benar kering. Cahaya matahari sangat membantu dalam proses kematian gulma, yang mana semakin panas sinar matahari maka proses kematian gulma semakin cepat. Oleh karena itu aplikasi bagus dilakukan pada siang hari.

Setelah kegiatan sosialisasi dan demo, kegiatan selanjutnya yaitu memantau masyarakat yang dapat membuat larutan tersebut dan mengaplikasikannya secara mandiri. Proses tindak lanjut oleh masyarakat dipantau oleh tim pengabdi dan dokumentasinya terlampir dalam lampiran.

Masyarakat telah mengetahui fungsi masing - masing bahan dalam herbisida ramah lingkungan ini setelah disosialisasikan. Asam cuka berfungsi sebagai pendestruksi atau penghancur jaringan gulma. Garam bersifat higroskopis atau suka air sehingga garam dapat mendehidrasi atau mengisap air pada jaringan gulma. Selain itu, garam berperan untuk mendenaturasi protein pada gulma sehingga memblokir keberlangsungan metabolisme. Larutan sabun memiliki bagian hidrofilik dan hidrofobik sehingga berperan meningkatkan efektifitas penempelan larutan herbisida ini pada permukaan gulma mengingat jaringan gulma memiliki lapisan lilin yang hidrofobik sedangkan herbisida bersifat hidrofilik.

\section{Intensitas penggunaan herbisida}

Intensitas penggunaan herbisida sintetik mengalami perubahan dalam tiga tahun terakhir. Pengolahan data quisioner 1 dan 2 diperoleh sebuah grafik yang menerangkan kondisi ini dan dapat dibandingkan dengan herbisida ramah lingkungan. Data ini ditampilkan dalam grafik pada gambar 4.2.

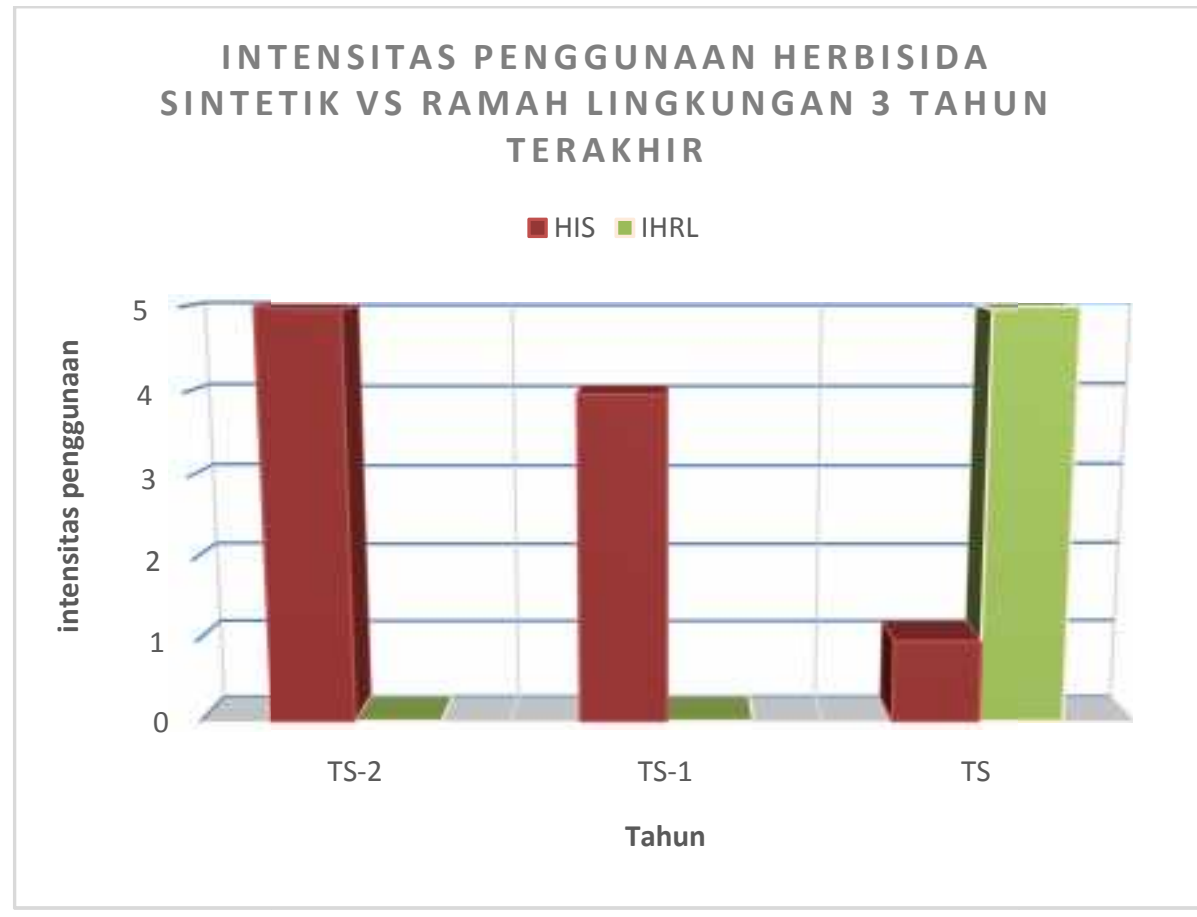

\section{Gambar 4.2 Grafik intensitas penggunaan herbisida sintetik vs ramah lingkungan}

Gambar 4.2 memperlihatkan bahwa intensitas penggunaan herbisida sintetik telah menurun selama 3 tahun yaitu 2 tahun sebelumnya (TS-2) adalah 5 kali, 1 tahun sebelumnya 
(TS-1) adalah 4 kali dan tahun saat ini (TS) adalah 1 kali. Hal ini berbeda dengan intensitas penggunaan herbisida ramah lingkungan yaitu TS-2, TS-1, TS berturut-turut adalah 0,0 , dan 5 kali. Penggunaan herbisida ramah lingkungan tidak ada pada tahun sebelumnya karena masyarakat belum tahu membuat herbisida ini, sedangkan pada tahun ini 5 anggota kelompok tani masing - masing satu kali telah mencoba mengaplikasikan metode ini di sekitar pekarangan rumah atau kebun mereka.

Alasan warga tidak menggunakan herbisida sintetik hingga saat ini berdasarkan hasil jawaban quisioner 2 adalah karena masyarakat mengetahui herbisida ini beracun, mahal dan kedapatperolehannya tidak mudah karena pemukiman warga jauh dari tokoh obat pertanian. Sedangkan, masyarakat setelah pelatihanan ini dapat mengaplikasikan informasi yang diperoleh dengan baik. Alasan mereka memilih menggunakan herbisida ini adalah karena murah, sifat racunnya rendah dan mudah dibuat dengan bahan-bahan tersedia di kios - kios terdekat. Berdasarkan monitoring dan pengamatan diperoleh informasi bahwa sebanyak 5 liter larutan dapat membunuh gulma dengan area seluas $48 \mathrm{~m}^{2}$. Penurunan intensitas penggunaan herbisida sintetik ini juga menunjukkan bahwa meningkatnya kepedulian masyarakat terhadap perbaikan ekosistem tanah pertanian dan perkebunan.

\section{SIMPULAN}

Berdasarkan data setelah dilaksanakannya kegiatan ini maka dapat disimpulkan bahwa:

1. Masyarakat anggota kelompok tani Nek'amnaut Desa Kiusili telah mengalami peningkatan pengetahuan baik herbisida sintetik maupun ramah lingkungan. Hal ini ditandai dengan nilai SP yaitu 24 menjadi 76, yang mana menunjukkan perubahan kategori tingkat pengetahuan masyarakat dari kategori tidak tahu menjadi tahu atau berpengetahuan baik. Presentase jumlah masyarakat yang mengalami perubahan kategori ini adalah 0 menjadi $83 \%$ dari total anggota kelompok tani yang ikut kegiatan pengabdian ini.

2. Terjadi peningkatan kemampuan masyarakat dalam membuat herbisida ramah lingkungan ditunjukkan dengan SK 0 menjadi 83. Hal ini menunjukkan perubahan kategori dari tidak mampu membuat menjadi sangat mampu membuat herbisida tersebut. Presentase jumlah masyarakat yang mengalami perubahan kategori tersebut adalah dari 0 menjadi $89 \%$.

3. Intensitas penggunaan herbisida sintetik terus menurun sebelum kegiatan pengabdian ini dalam tiga tahun terakhir. Walaupun demikian setelah kegiatan ini intensitas penggunaan herbisida ramah lingkungan meningkat. Alasan masyarakat karena tingkat racunnya rendah, murah, ketersediaan bahan dapat diperoleh dengan mudah dan pembuatannya mudah dibandingkan herbisida sintetik.

4. Penurunan intensitas penggunaan herbisida sintetik menunjukkan meningkatnya kepedulian masyarakat terhadap perbaikan ekosistem tanah pertanian dan perkebunan.

5. Sebanyak 5 liter larutan herbisida ramah lingkungan mampu membunuh gulma seluas $48 \mathrm{~m}^{2}$.

\section{UCAPAN TERIMA KASIH}


Ucapan terimakasih kepada Lembaga Penelitian dan Pengabdian Masyarakat (LPPM) Universitas Timor (Unimor) yang telah berkontribusi sebagai penyandang dana untuk kegiatan pengabdian ini. Ucapan terimakasih juga diberikan kepada mahasiswa program studi kimia unimor yang telah membantu sebagai demonstran sepanjang kegiatan pengabdian.

\section{DAFTAR PUSTAKA}

Budi,G.P. dan Hajoeningtijas, O. D., 2013,Penerapan Herbisida Organik Ekstrak AlangAlanguntuk Mengendalikan Gulma pada Mentimun, AGRITECH : Vol. XV No. 1, Juni $2013: 32-38$.

Budiyanto, M. A. K., 2016, Pembuatan Herbisida Organik di Kelompok Tani Sumber Urip-1 DesaWonorejo Kecamatan Poncokusumo Kabupaten Malang, JURNAL DEDIKASI, ISSN: 1693-3214, Vol. 13, Mei 2016: 75 - 82.

Budiyanto, M. A. K., 2017, Herbisida Organik, ISBN : 978-979-796-275-3, Universitas Muhammadiyah Malang: Malang

Frastika,D., Pitopang,R.,Suwastika, I N., 2017, Uji Efektivitas Ekstrak Daun Kirinyuh (Chromolaena Odorata(L.) R. M. King Dan H. Rob) Sebagai Herbisida Alami TerhadapPerkecambahan Biji Kacang Hijau (Vigna Radiata (L.)R.Wilczek) Dan Biji Karuilei (Mimosa Invisa Mart. ex Colla), Journal of Science and Technology, ISSN-p: 2338-0950, Vol., 6 (3),Desember 2017: 225 - 238.

Rao, V.S. 2000. Principles of WeedScience. Science Publishers Inc.,California, USA.

Talahatu, D. R., dan Papilaya,P.M., 2015, Pemanfaatan Ekstrak Daun Cengkeh (Syzygium Aromaticum L.) sebagai Herbisida Alami terhadap Pertumbuhan Gulma Rumput Teki (Cyperus Rotundus L.), Biopendix, Vol. 1, No. 2, Maret 2015: 149-159.

Utomo, D. W. S.,Nugroho A.,Sebayang,H.T., 2014, Pengaruh Aplikasi Herbisida Pra Tanam Cuka $\left(\mathrm{C}_{2} \mathrm{H}_{4} \mathrm{O}_{2}\right)$, Glifosat Dan Paraquat Pada Gulma Tanaman Kedelai,Jurnal Produksi Tanaman, Vol. 2, No. 3, April 2014: 213-220. 